\title{
Assessing China's Rural Reform Programs and the Lessons for Africa's Agriculture Development. A Review
}

\author{
Thomas Bilaliib Udimal (Corresponding author) \\ School of Management, Jiangsu University, \\ P. R. China. E-mail: tbudimal2007@yahoo.com
}

\begin{abstract}
Zhuang Jincai, Henry Asante Antwi, Chen Cong \& Owusu Samuel Mensah
School of Management, Jiangsu University, P. R. China.
\end{abstract}

Received: August 2, 2017 Accepted: August 16, 2017 Published: September 5, 2017

doi:10.5296/jas.v5i3.11806

URL: https://doi.org/10.5296/jas.v5i3.11806

\begin{abstract}
Since the 2008 global financial crisis, many African governments are now turning to China for the much needed loans and technical expertise to undertake developmental projects. Meanwhile China and Africa exhibited similar socio-economic conditions some three decades ago; high poverty rates and agrarian dominated economies with very low per capita incomes. However, in the past few years, even as Africa remains at the bottom of global economic rankings, China is progressively emerging as the world's economic powerhouse. This paper examines the literature on how China's rural reforms program facilitated the country's fast economic transformation. The reforms process brought about institutional reforms that brought immense changes in the agriculture sector. The institutional reforms led to an increase in public investment in the area of $\mathrm{R} \& \mathrm{D}$, irrigation, rural education, road, and electricity, which contributed to the growth in agricultural productivity and rural poverty reduction. It is these interventions brought in by the reforms that resulted in the miracle growth experienced by China.
\end{abstract}

Keywords: China, Reforms, Success, Lessons, African Agriculture 


\section{Introduction}

Since the 2008 global financial crisis, many African governments are now turning to China for the much needed loans and technical expertise to undertake developmental projects. Meanwhile China and Africa exhibited similar socio-economic conditions some three decades ago; high poverty rates and agrarian dominated economies with very low per capita incomes. Two in three mainland Chinese lived below a poverty line of $\$ 1$ a day and in Sub-Saharan Africa (SSA), it was around $40 \%$ of the population (Ravallion, 2009). However, in the past few years whilst sub-Saharan Africa remains at the bottom of global economic rankings, China is fast emerging as the world's economic power house, recently overtaking Japan to become the worlds' second largest economy and is now set to surpass the USA to be the largest before 2025 (Yao \& Wang, 2014). But perhaps a more remarkable achievement which has received less publicity has been China's ability to supply the food need of about $22 \%$ of the world's population with its little arable of $7 \%$ of the world's arable land (Dirmeyer et al., 2006). Even though farmland is a relatively scarce resource in china (Prändl-Zika, 2008), agriculture has made enormous contributions to poverty reduction and overall development (Chen, Jiang, Chen, Yang, \& Lin, 2006; Deininger, Jin, Xia, \& Huang, 2014; Huang, Yang, Zhigang, Rozelle, \& Ninghui, 2007). The sector produces a wide variety of products made possible by the wide diversity of agro-ecological production zones. These include major staple grains like rice, wheat, and corn; livestock products such as meat, wool, and dairy products, and horticultural and fishery products (Shenggen Fan, 1997).

Chinese agriculture development history is as old as the civilization processes of the Chinese nation its self (Ye, Wang, \& Li, 2002). Independent family farms, typically small, and fragmented land holding had been the traditional farming institution in rural China for thousands of years. Most farmers were landless peasants who rented land, commonly at exorbitant rates from individual landlords for cultivation. Soon after the birth of the Peoples Republic of China in 1949, the land was confiscated by the government without compensation and redistributed to peasant farmers (Shenggan Fan \& Pardey, 1997). Afterward, the adoption of communism and heavy industry-oriented development strategy in the mid-1950s pushed the government to switch to the promotion of agricultural collectivization and monopolized state procurement and marketing policies (Lin, 1997). The wide spread food shortages and famine which occurred in the early 1960s is widely attributed to such policies (Chang \& Wen, 1997). According to (Lin, 1997), the collective farming system and the monopolized procurement and marketing policies were so detrimental to work incentives that, despite sharp improvements in technology and increases in the use of modern inputs in the 1960s and 1970s, grain production in China barely kept pace with population growth and increasing demand. In order to increase output, comprehensive policy reforms were initiated in the late 1970s.

However, the reforms are widely acclaimed to have been successful, distributional and equity issues have been raised. The benefits for opening up the economy have not been evenly distributed to farmers in all parts of the country. Farmers in the more developed Eastern and Southern provinces of the country have benefited more than their counterparts in the less developed Western and Northern provinces (Shenggan Fan \& Pardey, 1997; Huang et al., 
2007). Some concerns are recently emerging about the sustainability of China's agriculture policy objectives of maintaining high self-sufficiency ratios for primary food commodities such as wheat, maize, and rice. Prändl-Zika (2008), has enumerated some inevitable uncertainties including:

- The still-growing population of China, which will demand increasing, amounts of staple foods.

- The ever- increasing need for land for construction and technical infrastructure which can reduce arable land more and more and

- Erosion and desertification, which are major dangers to China and are increasingly reducing arable land.

According to Chao, Bo, and Zhang (2006), China's agriculture sector is not without its problems as the sector continues to face great challenges, many of which are deeply associated with nutrient management practices. These issues re-echo the need for a continuous appraisal and re-strategizing, if China's agriculture can maintain the key role of providing sufficient food for $22 \%$ of the world's population.

But unlike China, which has seen much improvement in agriculture productivity and structural transformation of her economy over the last three decades, sub-Saharan Africa remains the poorest developing region of the world (Gupta, Pattillo, \& Wagh, 2009). Agriculture productivity in Africa lags considerably behind that of other continents, as well as the region's own potential (Jayne \& Rashid, 2013). However, the good news is that African Union (AU) leaders have recently shown their commitment to improve agriculture growth and productivity. This is demonstrated by the newly launched: New Partnership for African Development-Comprehensive Africa Agriculture Development Programme (NePAD-CAADP). While such commitments and efforts and laudable, experiences tend to suggest that, the solution to the lack of progress against poverty in Africa may not reside in just initiating a development program. Since the 1950s, Africa has seen no shortage of recipes for promoting development, including agriculture (Delgado, 1998). Therefore, Africa needs to take a closer look at the strategies adopted by other regions that have made great progress from similar situations confronting the continent today. China's rich experiences in agricultural development before and after the 1979 reforms could provide many valuable lessons for other developing countries (Lin, 1997). The literature on Chinese and African agriculture and rural development efforts abound. This paper reviews the literature and highlights critical lessons that could help shape Africa's agriculture policy direction.

\section{Selection Relevant Studies}

Literature on the China's reform process as well as African agriculture development and rural poverty is abundant and fast emerging. This study therefore, does not claim to have undertaken an exhaustive coverage of all relevant material. A Google search on the phrases "Chinese rural reforms and African agriculture" produced 36, 400, 000 and 148, 000,000 results respectively. The paper primarily draws on a selection of peer-reviewed publications in English language available online in two major academic article databases, namely; Elsevier (www.sciencedirect.com) and Springer (www.springerlink.com ). Relevant articles 
were searched using the following key words 'Chinese rural reforms and agriculture productivity growth' 'impact of Chinese reforms on growth and poverty reduction', 'the success factors of the Chinese rural reforms', 'challenges facing African agriculture development', 'improving African agricultural productivity growth', 'contributions of agriculture to growth and poverty reduction'. Recommended articles related to selected papers were also searched and this made rich contribution to the literature coverage. The Scholar Google search engine (http://scholar.google.com) was used to source grey literature as published by international organization such as; the United Nations (UN), the World Bank, The UN-Food and Agriculture Organization (FAO), African Union (AU)/ New Partnership for African Development (NePAD), the UN - Economic Commission on Africa (ECA), the African Development bank (AfDB), the Alliance for Green Revolution in Africa (AGRA), Global Development Network (GDN) and Publication catalogue of the French Agency for International Development (AFD) 2014 Edition. Publications were chosen for review following a criteria adopted by (Liu, Pieniak, \& Verbeke, 2013) as follows: (1) the studies that focused on rural reforms and productivity growth, (2) the studies conducted in China after the 1978 reforms, (3) the studies that provided insights and information about the role of agriculture, challenges and efforts to improve productivity in Africa and (4) the full-text article was available for review. Following these criteria, 46 publications between 1979 and 2014 were selected. Publications prior to Chinese reforms in 1978 were only retrieved for content checks but not included in the review. In addition, papers that discussed general economic and sustainable development processes were excluded from the review.

\section{Chinese Agricultural Policy Reforms}

\subsection{Drivers and Pressures of Chinese Agricultural Policy Reforms}

Realizing that collective farming system did not only fail to raise living standards but was responsible for the wide spread poverty and misery, the Chinese Communist Party leadership, initiated a series of sweeping rural reforms in 1979 after the death of Chairman Mao Zedong. With an aim of improving agricultural production, the reforms raised the long depressed state procurement prices for major crops, modified the approach of the collective system and increased budgetary expenditure on agricultural investments (Lin, 1992). Zhang and Carter (1997) have identified the major characteristics of the reforms process as follows: the replacement of the collective system with the Household Responsibility System (HRS); improving price incentives to farmers; abolishing the mandatory production planning; reduction in the scope of mandatory procurement, and the reopening of free markets. Though the initial reforms were designed to correct the shortcomings of the collective farming system, they continuously evolved to accommodate emerging challenges facing the economy. Lifshitz et al. (2006) have evaluated the agricultural policy reforms over a two decade period (1979-2000) and have identified five main policy regimes. After successfully replacing the collective farming system with the Household Responsibility System (HRS) in 1979, further reforms (the second reform period, 1985-1989), were undertaken to provide incentives for farmers to boost production. After five years of operating a rural market program, agricultural production decreased significantly, triggering inflationary pressures because of increases in food prices. Therefore, a third reform program (1990-1993) made up of a set of adjustment 
policies became necessary to correct the failures of the rural market programs. The market reforms remained incomplete, the development, which degenerated into different degrees of price and quantity controls and by elimination of domestic markets from international markets. In a matter of time a rebirth of self -sufficiency policies were introduced in 1994 making it the fourth reform within the period. After just after four years of operation, a new grain program was announced in 1998 marking the fifth round of policy reforms.

According to Huang and Rozelle the long history of overvaluation of China's currency the RMB for trade protection purposes was another key source of disincentive to farmers, negatively impacting on agriculture. Huang et al. (2007) have explained that due to the tradable status of agricultural commodities, China's exchange rate policy was working against the agricultural sector. That is why the exchange rate depreciation, which occurred after the reforms, increased the export agriculture's competitiveness, a key contributor to China's record export growth and the robust economic performance in the 1980s. The accession to the WTO in 2001 imposed further reforms to the Chinese economy in general and the agriculture sector in particular. China's WTO agreement continue to have some impact due to commitments to reduce export subsidies (Huang et al., 2007; Lifshitz et al., 2006).

\subsection{Impact of the Reform on Agriculture Growth and Productivity}

This section assesses the results of various studies that have reported on the effect of the Chinese agriculture reforms on agricultural growth and productivity. Generally, there appears to be some consensus among researchers on the positive impact of the series of reforms on Chinese agricultural growth and productivity in particular and the economy as a whole. Lin (1992) has argued that the success of agricultural reform greatly encouraged moderate political leaders to adopt a series of more market-oriented reforms in both the urban and rural sectors. Some very impressive productivity estimates attributed to the reforms have range from $18.0 \%$ to from $63.0 \%$ in various studies as shown in Table1 below. Disaggregating by sectors, the literature has revealed differences in productivity gains over the years. According to Shenggan Fan and Pardey (1997), cash crop production (including cotton, oil crops, and fruits) achieved notable success, generally exceeding the increase in grain production, whilst the performance of the animal and fishery sub-sectors were more impressive than that of the crop sector. According Lu (2002) China during the reforms' era, combined strategies characterized by far-reaching state interventions and with some market economic principles, which have resulted in crop-specific effects. Huang et al. (2007), found the impact of trade liberalization on output growth to be negative for wheat, maize, cotton, oil crops and sugar crops. In contrast, the impact was positive for rice, vegetable, fruits, meat and fish, or those commodities in which China has comparative advantage in the international market. We see a shift in productivity gains for cotton and oil crops from high to low between the two study periods of (Shenggan Fan \& Pardey, 1997) and (Huang et al., 2007). This is a reflection of different policy regimes influencing differently on the productivity of specific crops. Huang et al. (2007) have explained that the reforms imposed by China's accession to the WTO have largely favoured exportable products that were negatively protected prior to accession.

Apart from the variations in sector specific productivity occasioned by the reforms, regional 
disparities in productivity patterns have also been observed. Shenggan Fan and Pardey (1997), have observed the rate of agricultural output increase in the northeastern and southern regions to be much faster than the national average. However, the central region as well as the northwest and southwest regions showed long run rates of growth some $8 \%$ to $15 \%$ below the national average. Huang et al. (2007) have reported that unlike farmers in the more prosperous eastern and southern provinces that produce more exportable products, average farmers in many less developed provinces in western and northern parts of China have not gained from trade liberalization. However, the larger picture of the Chinese reform process point to a success story (Table 1). Commenting on the success of the China's rural reform process, (Ravallion, 2009), has asserted that the 'generic point that freer markets can serve the interests of poor people has been well illustrated by the Chinese story. Noting that, China's farmers responded dramatically to market incentives when the institutional reforms gave them the chance to do so.

Table 1. Effects of Reforms on Agriculture productivity in China

\begin{tabular}{|l|c|c|}
\hline Author (s) & Studied Period & $\begin{array}{r}\text { \% boost in Agriculture } \\
\text { Attributed to Reforms }\end{array}$ \\
\hline Lin (1987) & $1980-1983$ & 62.0 \\
\hline McMillan, Whalley, and Zhu & $1978-1984$ & 51.8 \\
\hline Fan (1991) & $1965-1985$ & 63.0 \\
\hline Carter and Zhong & $1979-1986$ & 19.5 \\
\hline Lin (1992) & $1970-1987$ & 46.9 \\
\hline Huang and Rozelle & $1975-1990$ & 35.6 \\
\hline Zhang and Carter & $1980-1990$ & 18.0 \\
\hline Fan and Pardey ( 1997) & $1965-1993$ & \\
\hline
\end{tabular}

\subsection{The Sources of Growth}

Following the impressive showing of agricultural output after the reforms, scholars of China's economic development process have been investigating the sources of productivity growth since the early 1990s. In one of such studies, Lin (1992) highlights the positive impact of the institutional reforms. He reports that the household responsibility system, which was introduced to correct the failures of the collective farming system, had a very strong positive influence on productivity growth during 1978-84 periods. According to him, institutional changes accounted for about $96 \%$ of changes in productivity experienced within the period, which brought in to being the system of household responsibility. The positive influences of the market reforms on productivity growth have also been reported. Shenggan Fan and Pardey (1997) have quantified the effects of influential growth factors on Chinese 
agricultural performance since 1965 . They reported that the increased use of traditional inputs such as land and labor though beneficial, did not contribute much to the gains in agricultural output. Rather, the key role of the growth-promoting effects of 'getting markets right under the market reforms program were significant. Lifshitz et al. (2006) have argued that the institutional changes have in no doubt shown to have accelerated the rate of development of the Chinese agricultural sector. McMillan, Whalley, and Zhu (1989) attribute about $78 \%$ of the farm productivity gains between 1978 and 1984 to changes in the incentive system following the introduction of the household responsibility system and that the remaining $22 \%$ of the gains came from the market reforms which gave higher prices to producers. Exchange rate depreciation following the reforms has also been cited as a major driver of the increased export competiveness of agricultural products contributing to China's record of rapid export growth and robust economic performance of the 1980s (Huang et al., 2007).

Though the impact of the reforms on productivity growth is not in doubt, questions have since emerged among scholars regarding the extent of the impact. Shenggan Fan and Pardey (1997) use a panel data set which included agricultural research or stock-of-knowledge variable for analysis. They find that the direct growth promoting consequence of institutional change and market reforms may have been overstated by earlier studies. According to them, research-induced technical change accounted for a significant share thus $20 \%$ of the growth in agricultural output since 1965. Shenggen Fan, Zhang, and Zhang (2004) widened the scope of analysis by examining the specific role of different types of government expenditure on growth and poverty reduction in rural China. Their results show that government spending on production-enhancing investments, such as agricultural R\&D and irrigation, rural education, and infrastructure (including roads, electricity, and telecommunications) all contributed to agricultural productivity growth and reduced rural poverty. They admit that, during the period 1978-84, institutional and policy reform was the dominant factor both in promoting growth and in reducing rural poverty. However, from 1985-2000, public investment surpassed institutional and policy reform to become the largest source of production growth and poverty reduction.

With interest in the impact of the China's reforms on productivity growth, some researchers have gone a step further by decomposing productivity change into technical and allocative efficiency, and technical progress. SG Fan (1990) estimated land, labor and total factor productivity at the national and regional levels. He attributed the $70 \%$ productivity growth over the period 1965-1986 to an increase in input use. The remaining 30\% the study attributed to technical efficiency change and technical change. The study by $\mathrm{Wu}$ (1992), which covered the period 1985-1991, associated over 70\% of total factor productivity growth to technical change. The technical efficiency, the study however said decreased within the period and even became negative in the late 1980s. Carter and Estrin (2001) also estimate a multiple-output stochastic production frontier from 1986 to 1995. They attributed allocative inefficiency experienced in 1980s and 1990s to grain self-sufficiency policies and incomplete market reforms pursued by government at the time. A study by Lifshitz et al. (2006) undertake an identification and measurement of the composition of productivity development in the Chinese farming sector in the 1980s and 1990s reform periods. The study revealed that 
China's second reform in the period 1985-1989 witnessed the most rapid change in productivity growth. They attribute around $11 \%$ increase in productivity growth per annum to an improvement associated to technical change with virtually unchanged technical efficiency. They observe that the aggressive, but incomplete, market oriented reforms pursued by the government in the mid 1980s almost increased productivity growth and technical efficiency, but this they said did not lead to remarkable improvements in allocative efficiency. However, Total Factor Productivity growth and technical efficiency consecutively assumed a downward turn in the 1990s, as more unfriendly market reforms were implemented. The literature generally provides some strong support to the success of the Chinese rural/agricultural reforms process. The reforms have undoubtedly contributed significantly to the growth and transformation of the Chinese economy as we see today. In the next section, we turn our attention to understanding African agriculture, with respect to its role, the challenges, and the way forward. The section concludes with pointers to the lessons that Africa can learn from the Chinese experience as discussed above.

\section{Understanding African Agriculture}

\subsection{Agriculture Remains Dominant in African Economies}

The $21^{\text {st }}$ century has witnessed the expansion of markets and accelerated technology development. The accompanying structural transformation of economies has seen a decline in the share of agriculture's contribution to GDP (Brinkley, 2006; Dethier \& Effenberger, 2012; Economic \& Department, 2005; Valdés \& Foster, 2010). According to the Economic and Department (2005), agriculture now contributes merely 3 percent to global GDP, which is only about one third of its contribution a few decades ago. In the advanced industrial and knowledge based economies such as the USA, UK and Germany agriculture's contribution to GDP is a mere $1 \%$ (Brinkley, 2006). Although sub-Saharan Africa is also witnessing a decline in the quantum of agriculture's contribution to economic activity, its role in this region is still very significant. Here, agriculture remains the backbone of most economies, providing 60 percent of all employment, generating most of the much needed foreign exchange, and still the main generator of savings and tax revenues (Ulimwengu \& Sanyal, 2011). There are a few exceptions though, for instance in Africa's economic power house (the republic of South Africa) and oil rich Angola, the contribution of agriculture to the GDP works up to about 3\% and $10 \%$ respectively as shown Table 2 below. In the majority of sub-Saharan African countries, agriculture still contributes more than $20 \%$ to GDP, signifying its prominent role in the region. It is worth noting that because of the predominantly rural population base of many sub- Saharan African countries, a vast majority of them earn their main living from agriculture even in the few countries where agricultures contribution to GDP is not so high (Gabre-Madhin \& Haggblade, 2004; Jayne \& Rashid, 2013; Wiggins, 2000).

Despite having the largest share of its population engaged in agriculture, Africa has been unable to feed itself for many decades now (Salami, Kamara, \& Brixiova, 2010). The situation is even more grim in sub-Saharan Africa (SSA) where up to 240 million $30 \%$ of the population) are food insecure (Dubois, 2011). This state of affairs pertains despite the many years of substantial socio-economic gains in many African countries in the recent past. But 
perhaps more startling are projection that more SSA inhabitants will suffer from hunger and malnutrition in the foreseeable future (Salami et al., 2010; Shiferaw et al., 2013). Salami et al. (2010) have projected that the number of undernourished people in SSA will swell from 180 million in 1995/97 to 184 million by 2015. A clear indication that SSA is in fact left out of the UN- Millennium Development Goal of halving hunger and poverty by 2015. These developments have left many scholars wondering whether the traditional philosophy of agriculture leading the way to economic prosperity as recently experienced in China and most other Asian countries is applicable in the African situation (Diao, Hazell, \& Thurlow, 2010).

Table 2. Agriculture Contribution to the GDP of Top 10 Largest Economies of Sub-Saharan African Countries

\begin{tabular}{|l|l|l|l|l|}
\hline Country & $\begin{array}{c}\text { GDP (millions } \\
\text { of US dollars) }\end{array}$ & \multicolumn{3}{|l|}{ Agriculture, value added (\% of GDP) } \\
\hline & & $\mathbf{2 0 1 0}$ & $\mathbf{2 0 1 1}$ & $\mathbf{2 0 1 2}$ \\
\hline South Africa & 384,313 & 3 & 2 & 3 \\
\hline Nigeria & 262,597 & 30 & 31 & 33 \\
\hline Angola & 114,147 & 10 & 9 & 10 \\
\hline Sudan & 58,769 & 25 & 24 & 28 \\
\hline Ethiopia & 41,505 & 46 & 46 & 49 \\
\hline Ghana & 40,711 & 30 & 25 & 23 \\
\hline Kenya & 40,697 & 25 & 28 & 30 \\
\hline Tanzania & 28,242 & 28 & 28 & 28 \\
\hline Cameroun* & 25,322 & & & \\
\hline Cote & 24,680 & & & \\
\hline d'Ivoire* & & & & \\
\hline
\end{tabular}

Compiled from World Bank publications for the year 2012

*No information on agriculture contribution to GDP

\subsection{Interrogating the Challenges of African Agriculture}

However, why has African agriculture failed to create wealth and provide enough food for its people? Is the question researchers should delve much into. Scholars on African agriculture have been discussing a myriad reason believed to be responsible for the situation. Wiggins (2000), draws attention to the peasantry nature and the lack of modernization of African agriculture. Despite the availability of large uncultivated but suitable land, the average farm sizes in Africa are small (Jayne \& Rashid, 2013; Wiggins, 2000). They are typically less than 
three ha and farm sizes are on the decline as pressure from urbanization and rising population become more intense. Most agriculture tools used are basic and hand-held, tractors are rare and purchased external inputs - fertilizer, crop protection chemicals, improved seeds sparingly used (Jayne \& Rashid, 2013; Wiggins, 2000). Access to high quality, locally adapted, improved seed at affordable prices has long been recognized as an essential ingredient to boosting agricultural productivity (Jayne \& Rashid, 2013). In fact, Roy (2012) has described fertilizers, improved seed and irrigation as the 'technology trinity'- responsible for bringing about the success of the Green Revolution of Latin America and Asia. Adequate and efficient use of fertilizer should, therefore, be a main ingredient for achieving food security in sub-Saharan Africa (SSA) but fertilizer use intensity in SSA is very low, averaging just around $10 \mathrm{~kg} / \mathrm{Ha}$, whereas it has reached $222 \mathrm{~kg} / \mathrm{ha}$ in Asia, $160 \mathrm{~kg} / \mathrm{ha}$ in Oceania and $138 \mathrm{~kg} / \mathrm{ha}$ in South America.

The lack of modernization of African agriculture is not only limited to the use of traditional low yielding varieties and basic farm implements, but the reliance on natural rainfall is another source of drawback (Gabre-Madhin \& Haggblade, 2004; Haggblade, 2004; Namara, Hope, Sarpong, De Fraiture, \& Owusu, 2014; Wiggins, 2000). Despite the numerous research backed evidence that irrigation offers the best opportunity for increasing food production, and improving rural income and food security, only a small fraction of African farmland is irrigated: less than $5 \mathrm{M}$ ha, of which more than $3 \mathrm{M}$ ha lies in just two countries-Madagascar and the Sudan (Namara et al., 2014). As a result, much of African crop production is left to the mercy of favorable rainfall, which more often than not is highly unpredictable and unreliable. These and other natural hazards such as pest and disease attacks as well as poor soils are detrimental to agriculture (Gabre-Madhin \& Haggblade, 2004; Haggblade, 2004; Wiggins, 2000)

While productivity in African agriculture lags far behind the rest of the world (Diao et al., 2010), its population growth rate is faster ahead the rest of the world. It is intriguing that despite more than doubling its population size in the last 30 years (Gabre-Madhin \& Haggblade, 2004) the population of SSA is estimated to increase from 770 million in 2005 to between 1.2 -1.4 billion in 2025 and between 1.5- 2 billion in 2050 (Division, 1995). Such a high population growth rate has left the nature dependent peasant agriculture struggling to provide enough food for the inhabitants of SSA. The average food production per capita has persistently taken a downward trend, the development, which is putting large segments of the population at the risk of food insecurity and malnutrition (Abbott \& De Battisti, 2011). The growing number of mouths looking for food may not be the only problem associated with the high population growth rate of SSA but there is an associated growing disease burden, which is compounded by the debilitating HIV/AIDS pandemic.

Another major problem that has been identified in literature for the lack of progress in the living standards of the people of SSA is the inability of farmers to link their production to markets. Jayne and Rashid (2013) has identified the lack of efficient storage facilities, which combines with unavailability of inventory finance and limits the capacity of rural assemblers to absorb surpluses at harvest. This is seriously constraining efficient grain trade in Africa. The consequence is the very high postharvest losses estimated to range between $11 \%$ for rice 
and $19 \%$ for maize (Meenakshi et al., 2010). Without sure outlets, for the marketing of their produce, there is little incentive to produce more than what is required for subsistence and a little more for sale to buy necessities. Jayne and Rashid (2013) have noted that international agriculture trade agreements have brought dissatisfaction among developing countries, especially Africa countries as the agreement is affecting African agriculture negatively. Developing countries access to developed country markets has not been smooth, but many developing countries have rather experienced import surges following trade liberalization.

Institutional and leadership failures have also contributed in no small measure to the agriculture problems in SSA. They have failed to direct their investment into agricultural R\&D; rural infrastructure; access to markets and financial services; and policy support. Having received much attention from African governments, donors and the international community during the 1960s and 1970s, African agriculture suffered funding cuts in the 1980s and 1990s (Dethier \& Effenberger, 2012; Jayne \& Rashid, 2013). The over a decade long neglect and underinvestment for agriculture and agricultural R\&D in SSA has left many African countries struggling to catch up whilst more challenges such as declining soil fertility, water scarcity, the ease of spreading plant and animal diseases/pests, large but aging rural populations and climate change are emerging (Shiferaw et al., 2013).

Without doubt, land is one of the most critical resources for agriculture development. Proper management of land is therefore vital for improved agricultural productivity. As discussed in the Chinese experience, just a switch from the collective system to the household responsibility system greatly improved agriculture productivity. The interrelated problems of rural poverty, poor agricultural performance and low levels of economic growth have been attributed to the persistence of farming systems based on customary tenure (ECA, 2004; Jayne \& Rashid, 2013). Deininger et al. (2014) have stated that secure property rights to land can facilitate structural transformation in two ways. On the one hand, increased tenure security and the associated reduction of expropriation risk will increase investment incentives. On the other hand, formal documentation of rights, e.g., through certificates, makes it easier to unambiguously identify legitimate owners and thereby reduces the transaction cost of market-based land transfers. These benefits cannot be realized in the prevailing tenure arrangements in the majority of African countries.

Recognizing the limitations to agriculture development, African leaders, through the (Kolavalli, Flaherty, Al-Hassan, \& Baah, 2010), have outlined a complex set of challenges that needs urgent attention for the attainment of a productive and profitable agricultural/Agro-industrial sector. They are as follows:

- Low internal effective demand due to poverty;

- Poor and un-remunerative external markets (with declining and unstable world commodity prices and severe competition from the subsidized farm products of industrial countries);

- Vagaries of climate and consequent risk that deters investment;

- Limited access to technology and low human capacity to adopt new skills;

- Low levels of past investments in rural infrastructure (such as roads, markets, storage, rural electrification, etc.) essential for reducing transaction costs in farming and thereby increasing 
its competitiveness in serving production, processing and trade and

- Institutional weaknesses for service provision to the entire agricultural chain from farm to market.

\subsection{The Way Forward}

Going forward, agriculture remains the hope out of poverty in Africa. Despite the numerous challenges facing African agriculture, there is presently no better alternative for improving the welfare of the vast majority of Africa's poor (Dethier \& Effenberger, 2012; Diao et al., 2010; ECA, 2004; Economic \& Department, 2005; Jayne \& Rashid, 2013; Kibaara et al., 2009). According to the Economic and Department (2005), in resource poor countries, a given rate of GDP growth due to agricultural growth reduces poverty five times more than an identical dose of GDP growth due to non-agricultural growth and in sub-Saharan Africa; agricultural growth is 11 times more effective. Furthermore, emerging trends do not give any hope to Africa's industries making any meaningful contribution to poverty reduction in the near future. The small and poorly performing industrial sectors are facing increasing competition from large emerging economies like China and India, which may undermine any attempts to develop labor-intensive manufacturing sectors (Diao et al., 2010). Ravallion (2009) has argued that just as it happened in China, there will be a time when the emphasis in Africa will naturally shifts to secondary and tertiary sectors. Nevertheless, with the levels of poverty prevailing in SSA, an agriculture-based strategy must for now be at the center of any effective route out of poverty.

It seems right to argue that the present challenges facing African agriculture are in fact less serious compared with the state of depravity that existed in rural China prior to the reforms, yet millions have since been lifted out of poverty. So what did the Chinese do right? Can Africa learn from it? The next section attempts to provide some answers to these critical questions.

\section{Key Lesson for African Agriculture Development from the Chinese Experience}

Cognizant of the challenges facing the agriculture sector, the renewed commitment among African leaders to fighting poverty and hunger through agriculture development is refreshing. On the $31^{\text {st }}$ of January 2014, African Union (AU) member states officially adopted a target at a summit in Addis Ababa, Ethiopia to end hunger on the continent by 2025. Under the framework of the New Partnership of African Development (NePAD), an initiative of the African Union, many African countries pledged to spend $10 \%$ of their government budget on agriculture (Kibaara et al., 2009; Namara et al., 2014). Dubbed the Comprehensive African agriculture Development Programme (CAADP), the NePAD- CAADP will focus on investment in three key "pillars" believed to have a potential of making the earliest difference to Africa 's agricultural crisis, plus a fourth long-term pillar for research and technology. The three pillars are; extending the area under sustainable land management and reliable water control systems, improving rural infrastructure and trade-related capacities for market access, and increasing food supply and reducing hunger.

While such commitments and efforts are laudable, Africans cannot afford to ignore valuable lessons from other regions that have made great progress from the problems currently 
confronting Africa today. The success of china's rural reforms programs obviously provides great opportunities for learning. Surely, it will be naive not to recognize the fundamental differences between China and Africa. Notable among these differences is the fact that China is one big country; while Africa is made of several countries with different political structures and leadership styles. Certainly, constraints such as economic integration and policy coordination in Africa will be different from that of China (Ravallion, 2009). However, a number of policy messages worth considering in an African context can be gleaned from the Chinese experience in fighting poverty. Shenggen Fan et al. (2004) provides us with the first hint of policy direction. According to them before the Chinese rural reforms began; policy and institutional barriers inhibited the effects of government investment. The reforms reduced these barriers, enabling investments to generate tremendous economic growth and poverty reduction. China has had a long established tradition of building and maintaining strong administrative capacities of government at all levels. The strong institutional administrative capacities were very instrumental at the forefront of implementing the crucial rural reforms that started in the late 1970s (Ravallion, 2009). Certainly, it is not the lack of development ideas that has left Africa without much progress against poverty over the last century. African governments and their partners need to invest in the institutions, procedures, and people capable of mobilizing local ownership, broad knowledge, and unwavering commitment for development (Delgado, 1998). Indeed strong institutions are so critical for development as re-echoed by the first black president of the USA in his first visit to SSA remarked. "Development depends upon good governance. That is the ingredient which has been missing in far too many places, for far too long," "Africa doesn't need strongmen, it needs strong institutions" (Obama, 2009). The capacity of economic and governance institutions in Africa to implement policies is necessary for success, that capacity must be developed alongside other interventions as outlined in the NePAD- CAADP strategy document, if Africa is to expect any good results from the new commitment of the leadership to agriculture. Going by the Chinese experience then the NePAD-CAADP, certainly needs a fourth pillar on the development of capacities of economic and governance institutions at all levels. Africa is clearly lagging behind in building the capacity of her economic institutions (Ravallion, 2009). Institutional weaknesses for service provision to the entire agricultural chain from farm to market has been rightly identified as a challenge in NePAD- CAADP strategy document requiring urgent action, what is missing in that document is a prioritized action to addressing the challenge.

\section{Conclusion}

This paper provides a review of the Chinese rural reforms programs, which began in the late 1970s. The drivers, impacts, and sources of growth and productivity attributable to the reforms as presented in literature have been discussed. The present state of development and the challenges facing African agriculture as well as efforts been made to ameliorate the challenge and spur growth are also discussed. It is evident that the rural /agricultural reforms embarked upon in China three decades ago have contributed to the growth and structural transformation of the Chinese economy. Strong institutional and administrative capacities at all levels in China played a lead role in the success of the rural reforms. 
For Africa to make progress in the area of agricultural productivity there is an urgent for increase public investment in $\mathrm{R}$ and $\mathrm{D}$, irrigation, rural education, roads and electricity. Inputs for farmers should be the top most priority of all governments if they actually desire to see an improvement in agricultural productivity. The roads linking farming communities to the market centers should be given serious attention. Improved road networks will result in decrease in the cost of transporting farm produce to the market centers, hence influencing positively on both producers and consumers income. Investment in rural electrification is expected to boost agricultural productivity since farmers and processors alike will rely heavily on it in the processing of their produce.

For Africa to move out of its current state of agricultural productivity prioritizing the public investment in agriculture sector will be the surest way to go, thus if China's experience is anything to go by.

\section{Acknowledgements}

National Natural Science Foundation of China (NSFC) funded this research work, with grant number 71473106.

\section{References}

Abbott, P., \& De Battisti, A. B. (2011). Recent global food price shocks: Causes, consequences and lessons for African governments and donors. Journal of African Economies, 20(suppl 1), i12-i62. https://doi.org/10.1093/jae/ejr007

Brinkley, I. (2006). Defining the knowledge economy. London: The work foundation, 19.

Carter, C. A., \& Estrin, A. J. (2001). Market reforms versus structural reforms in rural China. Journal of comparative economics, 29(3), 527-541. https://doi.org/10.1006/jcec.2001.1732

Chang, G. H., \& Wen, G. J. (1997). Communal dining and the Chinese famine of 1958-1961. Economic Development and Cultural Change, 46(1), 1-34. https://doi.org/10.1086/452319

Chao, G., Bo, S., \& Zhang, T.-L. (2006). Sustainable Nutrient Management in Chinese Agriculture: Challenges and Perspective11Project supported by the Knowledge Innovation Program of Chinese Academy of Sciences (Nos. KZCX3-SW-417 and KZCX2-413). Pedosphere, 16(2), 253-263.

Chen, G., Jiang, M., Chen, B., Yang, Z., \& Lin, C. (2006). Emergy analysis of Chinese agriculture. Agriculture, ecosystems \& environment, 115(1), 161-173.

https://doi.org/10.1016/j.agee.2006.01.005

Deininger, K., Jin, S., Xia, F., \& Huang, J. (2014). Moving off the farm: land institutions to facilitate structural transformation and agricultural productivity growth in China. World development, 59, 505-520. https://doi.org/10.1016/j.worlddev.2013.10.009

Delgado, C. L. (1998). Africa's changing agricultural development strategies: past and present paradigms as a guide to the future. The Brown Journal of World Affairs, 5(1), 175-214.

Dethier, J.-J., \& Effenberger, A. (2012). Agriculture and development: A brief review of the 
literature. Economic Systems, 36(2), 175-205. https://doi.org/10.1016/j.ecosys.2011.09.003

Diao, X., Hazell, P., \& Thurlow, J. (2010). The role of agriculture in African development. World development, 38(10), 1375-1383. https://doi.org/10.1016/j.worlddev.2009.06.011

Dirmeyer, P. A., Gao, X., Zhao, M., Guo, Z., Oki, T., \& Hanasaki, N. (2006). GSWP-2: Multimodel analysis and implications for our perception of the land surface. Bulletin of the American Meteorological Society, 87(10), 1381-1397.

https://doi.org/10.1175/BAMS-87-10-1381

Division, U. N. P. (1995). World population prospects: the 1994 revision (Vol. 145): United Nations.

Dubois, O. (2011). The state of the world's land and water resources for food and agriculture: managing systems at risk: Earthscan.

ECA, U. (2004). Land tenure systems and their impacts on food security and sustainable development in Africa. United Nations Economic Commission for Africa, Addis Ababa.

Economic, A. O. o. t. U. N., \& Department, S. (2005). The State of Food Insecurity in the World 2005: Eradicating World Hunger-Key to Achieving the Millennium Development Goals: Food \& Agriculture Org.

Fan, S. (1990). Regional productivity growth in China's agriculture: Westview Press Inc.

Fan, S. (1997). Production and productivity growth in Chinese agriculture: new measurement and evidence. Food Policy, 22(3), 213-228. https://doi.org/10.1016/S0306-9192(97)00010-9

Fan, S., \& Pardey, P. G. (1997). Research, productivity, and output growth in Chinese agriculture. Journal of development economics, 53(1), 115-137.

Fan, S., Zhang, L., \& Zhang, X. (2004). Reforms, investment, and poverty in rural China. Economic Development and Cultural Change, 52(2), 395-421.

https://doi.org/10.1086/380593

Gabre-Madhin, E. Z., \& Haggblade, S. (2004). Successes in African agriculture: results of an expert survey. World development, 32(5), 745-766.

Gupta, S., Pattillo, C. A., \& Wagh, S. (2009). Effect of remittances on poverty and financial development in Sub-Saharan Africa. World development, 37(1), 104-115.

Haggblade, S. (2004). Building on successes in African agriculture: International Food Policy Research Institute.

Huang, J., \& Rozelle, S. Trade Liberalization, Rising Imports and China's Food Economy: The Case of Soybeans.

Huang, J., Yang, J., Zhigang, X., Rozelle, S., \& Ninghui, L. (2007). Agricultural trade liberalization and poverty in China. China Economic Review, 18(3), 244-265.

Jayne, T., \& Rashid, S. (2013). Input subsidy programs in sub-Saharan Africa: a synthesis of 
recent evidence. Agricultural Economics, 44(6), 547-562. https://doi.org/10.1111/agec.12073

Kibaara, B., Gitau, R., Kimenju, S., Nyoro, J., Bruntrup, M., \& Zimmermann, R. (2009). Agricultural policy-making in Sub Saharan Africa: CAADP progress in Kenya: Egerton university. Tegemeo institute of agricultural policy and development.

Kolavalli, S., Flaherty, K., Al-Hassan, R., \& Baah, K. O. (2010). Do Comprehensive Africa Agriculture Development Program (CAADP) processes make a difference to country commitments to develop agriculture? The case of Ghana. International Food Policy Research Institute (IFPRI), discussion paper, 1006.

Lifshitz, E., Brumer, M., Kigel, A., Sashchiuk, A., Bashouti, M., Sirota, M., . . Ledoux-Rak, I. (2006). Air-Stable PbSe/PbS and PbSe/PbSe x S1-x Core- Shell Nanocrystal Quantum Dots and Their Applications. The Journal of Physical Chemistry B, 110(50), 25356-25365.

Lin, J. Y. (1992). Rural reforms and agricultural growth in China. The American economic review, 34-51.

Lin, J. Y. (1997). Institutional reforms and dynamics of agricultural growth in China. Food Policy, 22(3), 201-212. https://doi.org/10.1016/S0306-9192(97)00009-2

Liu, R., Pieniak, Z., \& Verbeke, W. (2013). Consumers' attitudes and behaviour towards safe food in China: A review. Food Control, 33(1), 93-104.

https://doi.org/10.1016/j.foodcont.2013.01.051

Lu, W. C. (2002). Effects of agricultural market policy on crop production in China. Food Policy, 27(5), 561-573.

McMillan, J., Whalley, J., \& Zhu, L. (1989). The impact of China's economic reforms on agricultural productivity growth. Journal of political economy, 97(4), 781-807.

Meenakshi, J., Johnson, N. L., Manyong, V. M., DeGroote, H., Javelosa, J., Yanggen, D. R., . . . Meng, E. (2010). How cost-effective is biofortification in combating micronutrient malnutrition? An ex ante assessment. World development, 38(1), 64-75.

https://doi.org/10.1016/j.worlddev.2009.03.014

Namara, R. E., Hope, L., Sarpong, E. O., De Fraiture, C., \& Owusu, D. (2014). Adoption patterns and constraints pertaining to small-scale water lifting technologies in Ghana. Agricultural Water Management, 131, 194-203. https://doi.org/10.1016/j.agwat.2013.08.023

Obama, B. (2009). Remarks to the Ghanaian Parliament. Paper presented at the Accra International Conference Center Accra, Ghana.

Prändl-Zika, V. (2008). From subsistence farming towards a multifunctional agriculture: Sustainability in the Chinese rural reality. Journal of environmental management, 87(2), 236-248. https://doi.org/10.1016/j.jenvman.2006.10.028

Ravallion, M. (2009). Are there lessons for Africa from China's success against poverty? World development, 37(2), 303-313. https://doi.org/10.1016/j.worlddev.2008.06.001 


\section{Macrothink}

Journal of Agricultural Studies

ISSN 2166-0379

2017, Vol. 5, No. 3

Roy, A. H. (2012). Fertilizers and Food Production Handbook of Industrial Chemistry and Biotechnology, 959-995, Springer.

Salami, A., Kamara, A. B., \& Brixiova, Z. (2010). Smallholder agriculture in East Africa: Trends, constraints and opportunities: African Development Bank Tunis.

Shiferaw, B., Smale, M., Braun, H.-J., Duveiller, E., Reynolds, M., \& Muricho, G. (2013). Crops that feed the world 10. Past successes and future challenges to the role played by wheat in global food security. Food Security, 5(3), 291-317.

https://doi.org/10.1007/s12571-013-0263-y

Ulimwengu, J., \& Sanyal, P. (2011). Using a spatial growth model to provide evidence of agricultural spillovers between countries in the NEPAD CAADP framework. IFPRI Working Paper No. 01069.

Valdés, A., \& Foster, W. (2010). Reflections on the role of agriculture in pro-poor growth. World development, 38(10), 1362-1374. https://doi.org/10.1016/j.worlddev.2010.06.003

Wiggins, S. (2000). Interpreting changes from the 1970s to the 1990s in African agriculture through village studies. World development, 28(4), 631-662.

https://doi.org/10.1016/S0305-750X(99)00153-9

Wu, Y. (1992). Productivity performance of Chinese rural enterprises: A comparative study. Retrieved from

Yao, S., \& Wang, P. (2014). Has China displaced the outward investments of OECD countries? China Economic Review, 28, 55-71.

Ye, X., Wang, Z., \& Li, Q. (2002). The ecological agriculture movement in modern China. Agriculture, ecosystems \& environment, 92(2), 261-281.

https://doi.org/10.1016/S0167-8809(01)00294-8

Zhang, B., \& Carter, C. A. (1997). Reforms, the weather, and productivity growth in China's grain sector. American Journal of Agricultural Economics, 79(4), 1266-1277.

https://doi.org/10.2307/1244283

\section{Copyright Disclaimer}

Copyright for this article is retained by the author(s), with first publication rights granted to the journal.

This is an open-access article distributed under the terms and conditions of the Creative Commons Attribution license (http://creativecommons.org/licenses/by/4.0/). 